\title{
INTERNAL AUDIT OF THE SUPPLY CHAIN MANAGEMENT IN FUNCTION OF COST REDUCTION OF THE COMPANY
}

\author{
Milan PASULA ${ }^{1}$, Branislav NERANDŽIĆ ${ }^{2}$, Milan RADOŠEVIĆ ${ }^{2}$ \\ ${ }^{1}$ University of Novi Sad, Faculty of Technical Science, Novi Sad, Trg Dositeja Obradovića 6, Republic of Serbia. \\ E-mail: milan.pasula@gmail.com \\ ${ }^{2}$ University of Novi Sad, Faculty of Technical Science, Novi Sad, Trg Dositeja Obradovića 6, Republic of Serbia
}

Accepted 2 November, 2012

\begin{abstract}
The supply chain has major impact on the company's business strategy directly affecting its operational costs. Supply chain performances within the organization have a significant impact on the company's ability to provide services to their customers and create added value. Internal audit of the supply chain is one of the most powerful and fastest ways to reduce operational costs and provide the company competitive advantages in the global market in times of economic crisis. The aim of this paper is to present the key areas of internal audit activities in assessing risk and analyzing the functioning of the supply chain. The aim of internal audit is to make recommendations for improving the efficiency and effectiveness of operations and to help management in achieving the projected business goals. The subject of this paper is the analysis of various fields of internal audit of the supply chain as well as evaluating the characteristics of individual elements of the chain with consideration to appropriateness and integration of those elements. Moreover, this paper will give an answer to the question to what extent the operations within the supply chain contribute to the fulfilling of the development strategy of the company.
\end{abstract}

Keywords: internal audit, supply chain, operational costs

\section{INTRODUCTION}

As a result of the economic crisis companies are forced to analyze their business processes in order to reduce operating costs of business. Old cost impact strategies do not have the same effect as they once had. Traditional approaches based on improvement are also no longer adequate. Today under the influence of changes on a global level and under pressure to reduce costs the company diverts its attention to risk assessment, process management and environmental risks. Supply chain should not be viewed as a function that supports other functions, but as a separate activity which is involved in all functions of the company.

The definition of SCM given by The Global Supply Chain Forum is the following: »Supply chain management is the integration of key business processes from end-user through original suppliers that provides products, services, and information that add value for customers and other stakeholders « (Douglas, 2008). According to Douglas (2008), successful supply chain management requires crossfunctional integration within the firm and across the network of firms which comprise the supply chain. The function of internal audit aims to evaluate and contribute to the improvement of risk management processes, suggests setting up such process if necessary, but does not coordinate risk management of the company.

It is necessary to make a difference between cost savings and risk reduction, actually to regard them as different strategies that are often at the expense of one another. If a company wants seriously to dedicate itself to cost reduction, it must have access to contemporary ways and plan its actions and effects in the long term. Although internal audit bears certain costs in the short term as well as the risk management processes it encourages, in the long term its effects and actions may permanently lower the cost of doing business primarily through identifying risks. It must be noted that managers of the company remain primarily responsible for risk management while internal auditors have a proactive role in assisting the initial establishment of such a process, but they do not have to deal with or be responsible for identifying risks (Nerandžić, 2007). 
The main objective of this paper is to present fields of internal audit activities of supply chain processes with emphasis on establishing a system of assessment and risk management. The aim is to depict the types and effects of risks that affect the functioning of the supply chain, as well as their increased influence in the last decade that have led the company to deal with them, evaluate them and act before they occur in order to reduce future costs.

\section{INTERNAL AUDIT AND REASONS FOR ITS IMPLEMENTATION IN THE SUPPLY CHAIN PROCESS}

Financial statements, accounting and auditing provide relevant information on the financial position and performance of company's business. The need for improved financial reporting, accounting and auditing is a general trend in all financial systems. This is caused by the emergence of the financial crisis and the crisis in corporate governance (Sabovic et al., 2010). Responsibility for corporate governance lies on several organizational entities. Main participants in corporate governance are boards, executive management, internal auditors and external auditors (Beke-Trivunac, 2011). An especially interesting area of auditing is internal audit with the main task to be a support for the management of the company.

According to The Institute of Internal Auditors (IIA) internal auditing is defined as an independent, objective assurance and consulting activity designed to add value and improve an organization's operations. It helps an organization to accomplish its objectives by bringing a systematic, disciplined approach to evaluate and improve the effectiveness of risk management, control, and governance processes (http://www.theiia.org). One more comprehensive definition of internal audit explains it as a multi-step process aimed at determining whether existing processes and procedures (condition) comply with predetermined rules and regulations (the criteria) or deviate in any way from this standard (Kagermann et al., 2008). Internal audit adds value to the organization and its stakeholders by providing objective and contributing to the effectiveness and efficiency of corporate governance, risk management and control processes (Beke-Trivunac, 2011). Internal audit examines the organization and functioning of accounting systems and related internal controls, credibility of financial and operational information. It evaluates the economy, efficiency and effectiveness of business operations and controls, application of policies, plans and procedures and conducts special checks.
Unlike the audit of financial statements that is focused on testing and assessing of the reality and objectivity of financial reports which is traditionally done by external auditors, internal audit focuses on testing and assessing of business and increasing the success of the organization as a whole (Tušek and Sever, 2007).

According to General and Specific Standards for the Professional Practice of Internal Auditing issued by the IIA in 1978 and Performance Standards of the IIA process of internal audit should include:

- Audit planning (Engagement Planning) internal auditors should plan each audit;

- Examining and evaluating information (Performing the Engagement) - internal auditors should collect, analyze, interpret, and document information to support audit results;

- Communicating results - internal auditors should report the results of their audit work;

- Following up (Monitoring Progress) - internal auditors should follow up to ascertain that appropriate action is taken on reported audit findings (Pickett, 2003).

As it is presented, internal audit can be understood as a support for corporate managers. Namely, internal audits allow managers of larger production systems to delegate its oversights function to internal audit department. This is important for several reasons:

- Growing complexity of the operating environment due to automated data processing;

- Increased decentralization in physical location and decision making as a result of globalization or internalization;

- Lack of expertise required to conduct efficient, high - quality audits (Kagermann et al., 2008).

After analyzing definitions and some of the standards of internal audit, it can be concluded that this process can improve effectiveness and efficiency, and by that, the performances of many functions in one production system. Internal auditors unfortunately often push supply risk lower on the list of priorities (Salonen, 2010). High-impact supply chains win market share and customer loyalty, create shareholder value, extend the strategic capability and reach of the business. Independent research shows that excellent supply chain management can yield:

- $25-50 \%$ reduction in total supply chain costs;

- $25-60 \%$ reduction in inventory holding;

- $25-80 \%$ increase in forecast accuracy;

- 30-50\% improvement in order-fulfillment cycle time; 
- 20\% increase in after-tax free cash flows (http://www.scp-uk.co.uk).

To enhance supply chain integrity, companies should develop a framework for a structured approach to ongoing risk identification and management. This will enable businesses to proactively address organizational supply chain risks on a periodic basis - a practice that affords stronger company and brand protection against supply chain risk gaps (http://www.pwc.com).

\section{SUPPLY CHAIN STRUCTURE AND INTERNAL AUDIT TASKS INVOLVED}

There are different models of supply chain within the company and they are adapted to its complexity and the activity in which it is engaged. There is no ideal model that will provide the best setting to its results, but common processes are defined to operate inside an organization. The supply chain management processes identified by The Global Supply Chain Forum are:

- Customer Relationship Management;

- Supplier Relationship Management;

- Customer Service Management;

- Demand Management;

- Order Fulfillment;

- Manufacturing Flow Management;

- Product Development and Commercialization;

- Returns Management (Douglas, 2008).

All these processes are related supply chain features in all businesses, and also successful management of the supply chain requires the involvement of all of the corporate business functions. SCM offers the opportunity to capture the synergy of intra- and intercompany integration and management. In that sense, SCM deals with total business process excellence and represents a new way of managing the business and relationships with other members of the supply chain (Douglas, 2008). According to PricewaterhouseCoopers internal audit can contribute to company's security and success by:

- Reviewing and understanding supply chains, including their strengths and weaknesses, in developing markets, to validate monitoring programs;

- Working with the company's supply chain specialists to help develop a monitoring process that can be repeated;

- Helping to identify which suppliers are critical;

- Assessing which suppliers may be vulnerable to threats and helping draw up a residual mitigation profile;
- Identifying strong risk control procedures;

- Helping to develop key analytic tools and techniques;

- Aiding with compliance monitoring (www.pwc.com).

In response to the financial crisis, organizations are also charging their internal audit function with value-added roles to assist in formulating and achieving strategic objectives and sustainable growth. Internal audit of supply chain is to help company in finding answers to crucial questions about managing success factors of supply chain excellence, which can be divided into five main sections:

- Strategy - To determine if the enterprise has a clear strategy tuned to business expectations and focused on profitably servicing customer requirements;

- Organization - To determine if an effective organization structure exists enabling the enterprise to work with its partners to achieve its supply chain goals;

- Process - To determine if the enterprise has excellent processes for implementing its strategy, embracing all plan-source-make-deliver operations;

- Information - To determine if the enterprise has reliable information and enabling technology to support effective supply chain planning, execution and decision-making;

- Performance - To determine if the enterprise is managing supply chain performance in ways that will increase the bottom-line, cash flows and shareholder returns (http://www.scp-uk.co.uk).

\section{SUPPLY CHAIN RISK MANAGEMENT}

Internal Audit can work with business leaders to develop an appropriate supply chain risk management program to provide assessments of the supply chain risk management program through continuous monitoring and auditing. Before companies can devise effective means of reducing supply-chain risks, managers must first understand the universe of risk categories as well as the events and conditions that drive them (Table 1). Then, armed with clear, specific knowledge about these crucial risks, companies can proceed to select and tailor mitigation strategies, which are likely to be most effective.

President and CEO of the global consulting firm Protiviti, Joseph Tarantino, said that boards of directors and their audit committees must be aware of the hurdles and opportunities that lie ahead if 
business conditions remain uncertain in 2012 and be prepared to advise their organizations quickly and strategically. According to Protiviti, a global consulting firm, managing supply chain risks and rising commodity costs were included in the top ten business challenges for non-financial services firms (www.cfoinnovation.com).

The big challenge for managers is to mitigate risks by intelligently positioning and sizing supply chain reserves without decreasing profits. However, while stockpiling inventory may shield a company against delivery delays by suppliers, building reserves in an undisciplined fashion also drives up costs and hurts the bottom line. Other benefits of SCRM include the elimination of potential and unexpected costs, reduced disruptions and time to recover.

In addition to development methods and tools for managing its own supply chain risks, IBM has invested in several joint university programs to further explore topics related to supply chain risk. Among these was a survey designed to understand how supply managers attempt to manage risk in procurement. Their conclusion was that supply management professionals do recognize that risk exists in their upstream supply chains, though often it is discussed only when a problem occurs (www.ibm.com).

Table 1: Supply chain risk and their Drivers (Sunil and ManMohan 2004)

\begin{tabular}{|c|c|}
\hline $\begin{array}{l}\text { Category of } \\
\quad \text { risk }\end{array}$ & Drivers of risk \\
\hline Disruptions & $\begin{array}{l}\text { - Natural disaster } \\
\text { - Labor dispute } \\
\text { - Supplier bankruptcy } \\
\text { - War and terrorism } \\
\text { - Dependency on a single source of supply as well as the capacity and responsiveness of } \\
\quad \text { alternative suppliers }\end{array}$ \\
\hline Delays & $\begin{array}{l}\text { - High capacity utilization at supply source } \\
\text { - Inflexibility of supply source } \\
\text { - Poor quality or yield at supply source } \\
\text { - Excessive handling due to border crossings or to change in transportation modes }\end{array}$ \\
\hline Systems & $\begin{array}{l}\text { - Information infrastructure breakdown } \\
\text { - System integration or extensive systems networking } \\
\text { - E-commerce }\end{array}$ \\
\hline Forecast & $\begin{array}{l}\text { - Inaccurate forecasts due to long lead times, seasonality, product variety, short life cycles, small } \\
\text { customer base } \\
\text { - "Bullwhip effect" or information distortion due to sales promotions, incentives, lack of } \\
\text { supply-chain visibility and exaggeration of demand in times of product shortage }\end{array}$ \\
\hline $\begin{array}{l}\text { Intellectual } \\
\text { Property }\end{array}$ & $\begin{array}{l}\text { - Vertical integration of supply chain } \\
\text { - Global outsourcing and markets }\end{array}$ \\
\hline Procurement & $\begin{array}{l}\text { - Exchange rate risk } \\
\text { - Percentage of a key component or raw material procured from a single source } \\
\text { - Industry wide capacity utilization } \\
\text { - Long-term versus short-term contracts }\end{array}$ \\
\hline Receivables & $\begin{array}{l}\text { - Number of customers } \\
\text { - Financial strength of customers }\end{array}$ \\
\hline Inventory & $\begin{array}{l}\text { - Rate of product obsolescence } \\
\text { - Inventory holding cost } \\
\text { - Product value } \\
\text { - Demand and supply uncertainty }\end{array}$ \\
\hline Capacity & $\begin{array}{l}- \text { Cost of capacity } \\
\text { - } \quad \text { Capacity flexibility }\end{array}$ \\
\hline
\end{tabular}

\section{CONCLUSION}

According to many authors and researchers, internal audit can be used for improving supply chain process in terms of efficiency and effectiveness, by providing insight and recommendations based on analyses and assessments of available data from the company. Supply chain management is a very complex structure of activities with cross-functional processes, and it presents one of the most important functions in the company since it is directly linked to all functions of the company. Supply chain problems 
result from natural disasters, labor disputes, supplier bankruptcy, act of war or terrorism, systems breakdowns, procurement failures and other causes. Internal auditors have changed their roles of merely providing a check over accounting transactions into helping and providing support for companies in supply chain risk management. The supply chain internal audit aims to support managers in process optimization and above all in cost reduction which result from an uncertain environment by evaluating and directing management towards approaches which will prevent or reduce negative effects.

\section{REFERENCES}

Ten Major Business Challenges for 2012. Retrieved 14/02/2012from CFO Innovation Asia Staff http://www.cfoinnovation.com/content/10-majorbusiness-challenges-2012

Supply Chain Risk Management: A Delicate Balancing Act. (2008). Retrieved 30/01/2012, from IBM Global Business Services ftp://ftp.software.ibm.com/common/ssi/sa/wh/n/gbw0 3015usen/GBW03015USEN.PDF

Internal Audit perspectives: Increased level of supply chain risk joins growing chain of challenges. (2009). Retrieved 30/01/2012, from PricewaterhouseCoopers http://www.pwc.com/en_CA/ca/risk/internalaudit/publications/perspectives-supply-chain-risk2009-07-en.pdf

Beke-Trivunac, J. (2011). Uloga odbora i internog revizora u savremenom korporativnom upravljanju. Economy and Market Communication Review, 1(1),
116-128.

Kagermann, H., Kinney, W., Küting, K., \& Weber, C. P. (Eds.). (2008). Internal Audit Handbook: Management with the SAP-Audit Roadmap. Verlag, Berlin, Heidelberg: Springer.

Douglas, M. L. (2008). An Executive Summay of Supply Chain Management: Processes, Partnerships, Performance. Sarasota, FL: Supply Chain Management Institute.

Lascelles, D. Supply Chain Operations Audit. Retrieved 30/01/2012, from Supply Chain Planning UK Limited http://www.scp-uk.co.uk/audit.html

Nerandžić, B. (2007). Interna i operativna revizija. Novi Sad, Srbija: Stylos.

Pickett, S. K. H. (2003). The Internal Auditing Handbook (2 ed.). York, Chichester, etc: John Wiley \& Sons.

Sabovic, S., Miletic, S., \& Sabovic, S. (2010). The impact of the crisis on financial reporting, accounting and auditing. Technics Technologies Education Management, 5(3), 613 - 620.

Salonen, A. (2010). Reducing supplier risk. Strategic Finance, 91(12), 41-45.

Sunil, C., \& ManMohan, S. S. (2004). Managing Risk To Avoid Supply-Chain Breakdown. Mitsloan managament review, 46(1), 53-61.

Tušek, B., \& Sever, S. (2007). Uloga interne revizije u povećanju kvalitete poslovanja poduzeća u Republici Hrvatskoj-empirijsko istraživanje. Zbornik Ekonomskog fakulteta u Zagrebu, 5(1), 273 - 294.

Definition of Internal Auditing. Retrieved 28/12/2011, from The Institute of Internal Auditors http://www.theiia.org/guidance/standards-andguidance/ippf/definition-of-internalauditing/?search\%C2\%BCdefinition 